\title{
POTENSI KAWASAN GREMBENGAN MENJADI DESTINASI WISATA EDUKASI DI DESA BONGAN, TABANAN, BALI
}

\author{
Nelsye Lumanauw \\ Politeknik Internasional Bali \\ Email: nelsye.lumanauw@pib.ac.id
}

\begin{abstract}
Grembengan area is a potential destination for educational tourism. Lack of awareness, understanding and knowledge of community about tourist villages have given an impact on level of community awareness. Stakeholder of the area is prefer to focus on how to bring tourists rather than solving the problems. The purpose of this research is to identify potential of Grembengan with the concept of Attraction, Accessibility, Amenity, Package, Activities, Ancillary in Bongan Village and what obstacles are faced in developing the area to become educational tourism. Qualitative research method through Focus Group Discussion. The conclusion of this study is that Grembengan has potential to become educational tourism, by fulfilling the identification of tourism components 6A. Two major problems are lack of community involvement and waste management. Community involvement is needed in the form of community empowerment as a solution to problems, as well as to maximize efforts to develop educational tourism destination.
\end{abstract}

Keywords: Tourism Destinations, Educational Tourism, Tourism Village, Tourism Components.

\section{Pendahuluan}

Di tengah pandemi Covid-19, keberadaan desa wisata yang menyuguhkan keunikan alam dan budaya, kini menjadi destinasi wisata alternatif untuk melakukan kegiatan di ruang terbuka. Wisatawan atau masyarakat perkotaan mendapatkan edukasi berupa pengalaman baru dengan mengeksplorasi suasana pedesaan. Oleh karenanya, masyarakat desa harus memiliki kesadaran akan peluang dan kesiapan menangkap manfaat yang dapat dikembangkan dari kegiatan wisata edukasi pedesaan. 
Antara dan Arida (2015:17) menyebutkan wisata edukasi lebih berkaitan dengan keberlanjutan pengetahuan tentang pedesaan dan kehidupannya yang susah untuk didapatkan dalam pendidikan formal perkotaan. Pengetahuan tentang pedesaan yang diperoleh di pendidikan formal tidak selengkap dan detail dengan keadaan pedesaan itu sendiri, dibandingkan dengan pengalaman yang diperoleh saat berada langsung di desa. Pengetahuan dan pengalaman langsung berada di desa khususnya bagi wisatawan yang sudah terbiasa dengan kehidupan kota modern, menjadi tujuan utama ditawarkannya desa wisata sebagai tempat melakukan kegiatan dan pembelajaran. Setiap desa memiliki keunikan dan potensi masingmasing untuk menjadi destinasi wisata. Berbeda dengan objek wisata yang dibuat menggunakan bahan-bahan artifisial untuk menarik wisatawan, desa wisata justru menonjolkan kealamiahan suasana asri dan kehidupan masyarakat yang sederhana.

Desa Bongan yang terletak di Kecamatan Tabanan, Kabupaten Tabanan ditetapkan sebagai Desa Wisata tahun 2018 melalui Surat Keputusan Bupati Tabanan Nomor 180/ 457/ 03/HK \& HAM/ 2018, dengan tiga destinasi wisata andalan berupa situs bersejarah Kebo Iwa, Tradisi Mesuryak yang dilakukan setiap hari raya Kuningan dan Upacara Ngaben Tikus. Potensi desa harus diinventarisasi dan selanjutnya dikemas menjadi paket wisata edukasi yang bisa ditawarkan kepada wisatawan. Sebagaimana diungkapkan oleh Dewi dan Issundari (2013:65), semakin banyak wisatawan mancanegara tertarik datang ke desa wisata untuk belajar dan merasakan kehidupan sebagai masyarakat desa, akan meningkatkan soft power Indonesia di tataran internasional.

Selain mengandalkan ketiga destinasi tersebut, Desa Bongan juga memiliki destinasi pariwisata baru yang mulai dikenalkan pada bulan Februari 2020 dan dikelola oleh Kelompok Sadar Wisata (pokdarwis) Pesona Dewi Manis Bongan. Kawasan ini mulai dilirik wisatawan dan berpotensi menjadi pilihan kegiatan wisata edukasi. Wisatawan bisa mendapatkan pengalaman baru, menyatu dengan alam pedesaan, menghirup udara segar, lokasi yang jauh dari polusi dan kebisingan 
merupakan situasi yang akan dijumpai saat berada di kawasan Grembengan. Rambu yang bersikap edukatif untuk para wisatawan juga terpampang di kawasan tersebut, berupa larangan membuang sampah sembarangan, uraian sampah plastik dan anjuran penerapan protokol kesehatan. Kawasan hijau yang mengelilingi air terjun irigasi dan mata air tempat penyucian diri, serta keberadaan Pura Telaga Suman dengan sentuhan budaya barat (jaman penjajahan Belanda) menjadikan kawasan ini sebagai destinasi wisata edukasi yang ideal untuk dikunjungi.

Pura Telaga Suman yang berada di kawasan Grembeng menjadi salah satu obyek daya tarik wisata yang diteliti oleh Nuruddin (2020:82) dengan kesimpulan 'the efforts to make improvements by stakeholders there are still very few and have not experienced much renewal. Even so, it is unfortunate that some ancient buildings are buried in the ground and replaced with new (Pelinggih) statues on it. Upaya perbaikan oleh pihak pemangku kepentingan masih sedikit dan malahan beberapa bangunan arca kuno terkubur di dalam tanah dan diganti dengan patung baru (Pelinggih) di atasnya.

Seperti terungkap pada penelitian Nuruddin tersebut, kawasan Grembeng, khususnya penanganan Pura Telaga Suman adalah salah satu dari permasalahan yang dihadapi pengelola. Ketidakpahaman masyarakat terhadap benda bersejarah mengakibatkan arca kuno bagian pura yang memiliki nilai historis tinggi dibiarkan rusak dan terkubur, kemudian diganti menjadi bangunan baru. Kawasan penyucian di mana terdapat mata air, kolam mandi, sungai dan air terjun irigasi sering dipenuhi dengan sampah adalah kendala serius yang terjadi di kawasan ini. Kurang maksimalnya keterlibatan masyarakat juga menjadi tantangan tersendiri yang mengakibatkan penanganan kawasan tidak maksimal.

Besarnya potensi kawasan menjadi destinasi wisata edukasi, namun tidak diiringi dengan kepedulian masyarakat, membuat penelitian ini penting dilakukan. Dengan demikian, dua rumusan masalah ditetapkan guna menggambarkan kondisi kawasan, yaitu potensi apa saja yang terdapat di kawasan Grembeng berdasarkan 
identifikasi komponen pariwisata 6A (Attraction, Accessibility, Amenity, Package, Activities, Ancilliary) yang terdapat di Desa Bongan, Kabupaten Tabanan, Bali dan kendala yang dihadapi dalam mengembangkan potensi kawasan Grembengan menjadi wisata edukasi. Melalui jawaban terhadap kedua rumusan masalah tersebut, diharapkan bisa memberi pandangan jelas bagi pengelola terhadap tindakan yang sebaiknya dilakukan demi menggali potensi kawasan untuk menjadi destinasi wisata edukasi.

\section{Tinjauan Pustaka}

Penggalian tinjauan pustaka diperoleh dari kajian penelitian terdahulu sebagai perbandingan, konsep dan teori terkait masalah yang diteliti dan menjadi landasan penelitian. Teori dan konsep yang digunakan meliputi destinasi pariwisata, wisata edukasi dan komponen pariwisata 6A. Ketiga variabel menggambarkan pokok pikiran yang ingin disampaikan melalui penelitian ini.

\section{Destinasi Pariwisata}

Peraturan Menteri Pariwisata Republik Indonesia Nomor 14 Tahun 2016 mendefinisikan bahwa Daerah Tujuan Pariwisata yang selanjutnya disebut Destinasi Pariwisata adalah kawasan geografis yang berada dalam satu atau lebih wilayah administratif yang didalamnya terdapat daya tarik wisata, fasilitas umum, fasilitas pariwisata, aksesibilitas, serta masyarakat yang saling terkait dan melengkapi terwujudnya kepariwisataan. Lumanauw (2020:19) menyebutkan pariwisata merupakan industri jasa dengan mekanisme pengaturan yang kompleks, mencakup pengaturan pergerakan wisatawan dari daerah asal (original destination) ke destinasi pariwisata (tourism destination) hingga kembali ke negara asalnya. Dengan demikian, destinasi pariwisata kawasan Grembengan harus bisa menyediakan kenyamanan yang dibutuhkan, sehingga wisatawan mendapatkan pengalaman edukasi dari tempat yang dikunjungi. 
Eddyono, Fauziah (2021:72) menambahkan, secara umum unsur-unsur destinasi pariwisata terdiri dari unsur mutlak dan unsur pelancar. Kedua unsur tersebut harus terpenuhi dalam pembangunan destinasi pariwisata. Kriteria unsur mutlak mencakup daya tarik wisata, sumber daya manusia, produk wisata, nilai ekonomi wisata dan permintaan. Adapun kriteria unsur pelancar mencakup legalitas, sistem manajemen, aksesibilitas, sarana prasarana, arah pengembangan dan kebijakan, nilai sosial, nilai ekologi, dan pemangku kepentingan serta citra destinasi. Jika hanya salah satu syarat saja terpenuhi maka pengembangan destinasi pariwisata tidak bisa dilaksanakan dengan maksimal, kegiatan wisata tetap berjalan tetapi tidak ada pengembangan. Kawasan Grembengan harus memenuhi unsur mutlak dan pelancar untuk menarik wisatawan dan sekaligus memberikan manfaat bagi masyarakat desa.

\section{Wisata Edukasi}

Hariyanto, Oda I.B., dkk. (2018:15) dalam penelitiannya menyampaikan bahwa wisata edukasi merupakan diversifikasi produk wisata masa kini, berwisata sekaligus mendapatkan wawasan pengetahuan. Wisata edukasi membuka peluang usaha bisnis baru yang dapat mendorong pertumbuhan ekonomi dan mengurangi penganguran serta meningkatkan kesejahteraan masyarakat. Di samping itu, Harisandi dan Anshory (2019:128) menambahkan, wisata edukasi bertujuan untuk meningkatkan kecerdasan dan kreatifitas peserta kegiatan wisata yaitu tempat-tempat yang memiliki nilai tambah sebagai area wisata. Keunikan destinasi pariwisata kawasan Grembengan harus ditonjolkan sebagai nilai tambah untuk menarik wisatawan. Wisata edukasi menjadi alternatif peluang usaha bagi destinasi dan sebagai cara meningkatkan kesejahteraan masyarakat.

Penelitian Devi, Ida Ayu Sinta, dkk. (2018:140-141) menyebutkan bahwa wisata edukasi merupakan wisata yang produknya memberikan wawasan dan pendidikan selain menjadi tempat rekreasi, juga disebutkan untuk menarik kunjungan wisatawan 
agar mengadakan event juga yang mempunyai nilai edukasi, baik itu nilai edukasi mengenai pengetahuan lokal atau nilai edukasi mengenai atraksi yang dimiliki. Priyanto, Priyanto, dkk. 2018 menyimpulkan wisata edukasi merupakan suatu konsep pengelolaan kepariwisataan yang memadukan antara kegiatan wisata dengan kegiatan edukasi. Hal ini ditujukan agar wisatawan mendapatkan pembelajaran secara langsung di daya tarik wisata Kawasan Grembengan.

\section{Identifikasi Potensi Destinasi 6A}

Eddyono, Fauziah (2021:44-46) mengemukakan enam komponen utama dalam menganalisis destinasi pariwisata, yaitu Attraction, Accessibility, Amenity, Package, Activities, Ancilliary, seperti pada table 1. Identifikasi atraksi mencakup daya tarik wisata yang telah disiapkan di destinasi untuk dinikmati oleh wisatawan. Idenfitikasi aksesibilitas atau kemampuan untuk mencapai lokasi destinasi wisata melalui berbagai sarana transportasi. Amenitis adalah fasilitas pendukung yang diperlukan untuk mendukung kegiatan di kawasan pariwisata, untuk menciptakan kenyamanan bagi wisatawan di suatu destinasi wisata.

Penggabungan atraksi, aksesibilitas dan amenitis disebut dengan komponen available packages (paket wisata). Paket wisata merupakan produk wisata yang dikemas oleh perantara atau pelaku utama, untuk memudahkan wisatawan merasakan dan mengalami pengalaman berbagai atraksi, aksesibilitas, dan amenitis dalam satu kesatuan waktu perjalanan wisata.

Aktivitas merupakan kegiatan yang dilakukan wisatawan di destinasi tujuan selama kunjungan, seperti mengikuti event (acara) yang diselenggarakan. Ancillary services (layanan tambahan) adalah layanan pendukung yang akan digunakan wisatawan seperti bank, telekomunikasi, surat menyurat, dan rumah sakit. 
Tabel 1. Daftar Komponen Pariwisata

\begin{tabular}{ll}
\hline Atribut & Contoh \\
\hline Attractions & $\begin{array}{l}\text { Natural, buatan manusia, artifisial, dibuat dengan tujuan, warisan } \\
\text { budaya, event special. }\end{array}$ \\
& $\begin{array}{l}\text { Seluruh sistem transportasi yang termasuk pada rute, terminal } \\
\text { dan } \\
\text { Accesibility }\end{array}$ \\
kendaraan \\
Amenities & Akomodasi dan fasilitas katering dan layayan pariwisata lainnya \\
Packages & Aktivitas yang tersedia di destinasi dan apa yang wisatawan \\
Activities & dapat \\
Ancillary & lakukan selama kunjungan \\
services & bayanan pendukung yang akan digunakan wisatawan seperti \\
& telekomunikasi, surat menyurat, berita, rumah sakit.
\end{tabular}

Sumber: Eddyono, Fauziah (2021:45)

\section{Metode Penelitian}

Lokasi penelitian dilakukan di Kawasan Grembengan, Dusun Bongan Jawa, Desa Bongan, Kabupaten Tabanan, Bali pada bulan Desember 2020. Metode deskriptif kualitatif melalui pendekatan prosedur penelitian dan pengembangan (research and development) digunakan dalam penelitian ini, untuk mengidentifikasi komponen pariwisata 6A. Teknik pengumpulan data dilakukan melalui Focus Group Discussion (FGD) bersama anggota kelompok Pokdarwis Desa Bongan. Observasi dengan meninjau langsung lokasi kawasan Grembengan. Instrumen berupa dokumen, pedoman wawancara dan kamera. Instrumen dokumen mencakup penelitianpenelitian terdahulu, buku dan publikasi terkait destinasi pariwisata kawasan Grembengan. Publikasi terkait kawasan Grembengan masih relatif sedikit, mengingat destinasi ini masih baru dan belum popular baik di lingkungan masyarakat sekitar maupun luar Desa Bongan. Pedoman wawancara berupa sejumlah pertanyaan tertulis guna memperoleh data dari informan pada saat FGD. Penggunaan kamera diperlukan untuk mendokumentasikan pelaksanaan observasi lapangan sebagai penunjang penyajian data penelitian. 


\section{Pembahasan}

\section{Potensi Destinasi Pariwisata dengan Identifikasi 6A}

Pembahasan terhadap pengembangan potensi destinasi pariwisata Grembengan mencakup tahapan: attraction, accessibility, amenity, package, activities, ancilliary.

\section{Identifikasi Attraction}

Identifikasi atraksi berupa apa yang bisa dilihat dan dilakukan oleh wisatawan saat berada di kawasan Grembengan. Atraksi yang ditampilkan mempunyai nilai diferensiasi yang tinggi, unik dan berbeda dengan destinasi lain. Adapun atraksi yang terdapat di kawasan Grembengan meliputi:

a. Pura Telaga Suman dengan sentuhan arsitektur budaya barat (jaman penjajahan Belanda). Wisatawan bisa mempelajari sejarah pura dan membandingkan arca kuno dan bagian bangunan yang sudah direnovasi.

b. Pohon bunut berusia tua, berukuran dan berakar besar yang terletak di depan Pura Telaga Suman sehingga membuat lingkungan sekitar teduh. Pohon tersebut tampak seperti yang terdapat di Candi Angkor Wat.

c. Tempat penyucian diri (melukat) dengan sumber mata air dan pemandangan air terjun irigasi serta sungai.

d. Air terjun irigasi dan sungai. Kurangnya kesadaran masyarakat terhadap lingkungan area sungai, menyebabkan terjadi tumpukan sampah di sepanjang aliran air sungai.

e. Area luas di kelilingi pohon-pohon rindang bisa dimanfaatkan untuk yoga ataupun aktifitas outbound, camping ground. 
f. Proses pembuatan teh Gobo yang dibuat dari sayur gonda. Desa Bongan dan sekitarnya merupakan penghasil sayuran gonda. Melihat potensi ini, sekelompok masyarakat berinisiatif membuat sayuran gonda menjadi teh.

g. Ladang sayuran gonda dan berbagai tanaman rempah di sekitar area bisa menjadi pembelajaran bagi wisatawan yang ingin mengetahui berbagai jenis tumbuhan dapur.

h. Tempat makan di area terbuka dengan pemandangan pepohonan hijau yang asri dan alami, menyatu dengan suasana alam.

\section{Identifikasi Accessibility}

Identifikasi aksesibilitas berupa sarana prasarana dan infrastruktur menuju lokasi kawasan Grembengan. Akses jalan menuju kawasan Grembengan adalah jalan desa dengan kondisi cukup baik. Kawasan Grembengan yang tidak tepat di pinggir jalan dan tidak adanya penunjuk arah menuju lokasi maupun petunjuk di Google Map, serta masih adanya masyarakat yang tidak mengetahui keberadaan destinasi wisata baru ini menjadi kesulitan tersendiri mencari tempat tersebut. Pentingnya ketersediaan tanda penunjuk arah baik di titik-titik strategis jalan yang mudah dilihat oleh wisatawan dan melalui Google Map untuk mempermudah wisatawan menjangkau lokasi.

Kondisi jalan yang bagus menuju kawasan, tidak didukung dengan kondisi jalan setapak berupa anak tangga menuju air terjun yang masih berupa bambu, di samping keberadaannya yang sudah rapuh dan membahayakan bagi wisatawan. Berdasarkan informasi, keterbatasan dana menjadi kendala, sehingga belum bisa mengganti bambu dengan sarana yang lebih aman.

Permasalahan lain dan terjadi juga di destinasi wisata lain di Bali, yaitu aksesibilitas jalan yang baik menuju kawasan Grembeng tidak didukung dengan ketersediaan sarana transportasi umum. Wisatawan yang akan mengunjungi 
kawasan ini harus menggunakan kendaraan sendiri, baik milik sendiri maupun sewa ataupun melalui pengaturan dengan travel agent.

Identifikasi Amenity

Identifikasi amenitas berupa sarana, prasarana untuk memenuhi kebutuhan dan keinginan wisatawan selama berada di kawasan Grembengan. Kebutuhan peralatan dan perlengkapan sesuai protokol kesehatan telah disediakan di kawasan ini, seperti tempat cuci tangan dengan air mengalir, tempat sampah tertutup organik dan anorganik. Fasilitas pendukung yang terdapat di kawasan ini berupa listrik, air bersih, toilet dan tempat makan yang memadai. Sarana akomodasi berupa homestay atau pondok wisata untuk wisatawan yang ingin mengeksplorasi kawasan Grembengan dan sekitarnya, terletak tidak jauh dari kawasan. Homestay tersebut bernuansa pedesaan yang berada area tempat tinggal pemiliknya. Ketersediaan sarana akomodasi berupa homestay dimaksudkan juga sebagai media interaksi antara wisatawan dan masyarakat pedesaan.

Dengan menginap di rumah masyarakat, wisatawan bisa menyaksikan secara langsung bahkan turut terlibat dalam kegiatan kesehariannya, misalnya membuat sesajen, melihat anak-anak berlatih tarian tradisional, turut serta ke sawah menanam atau memanen padi dan sayur gonda yang menjadi ciri khas tanaman di desa ini. Wisatawan bisa mendapatkan pengalaman dengan mempelajari kehidupan masyarakat setempat dan menghargai kekayaan budaya yang dimilikinya.

\section{Identifikasi Package}

Identifikasi paket wisata di Desa Bongan mencakup pembuatan paket wisata yang dikemas oleh pihak pengelola destinasi sebagi tim operasional dan bekerja sama dengan perantara dalam hal ini, biro perjalanan wisata. Koordinasi awal secara detail oleh tim operasional terhadap pemandu wisata penting dilakukan sebelum pelaksanaan paket wisata (Lumanauw, 2020:61). 
Destinasi wisata Kawasan Grembengan dikombinasikan dengan produk wisata lain di Desa Bongan dan tetap mengacu pada ketiga komponen (Attraction, Accessibility, Amenity). Adapun contoh paket wisata yang direkomendasikan, yaitu Half Day Tour dan Full Day Tour dengan program sebagai berikut:

Paket Wisata Half Day Tour (pengelola destinasi merekomendasi obyek-obyek wisata mana yang bisa dikunjungi dalam waktu 4-5 jam atau setengah hari), dengan contoh program:

08.30: Penjemputan dari hotel di Nusadua/Kuta/Sanur/Ubud ke Desa Bongan.

09.30: Tiba di Desa Bongan, tamu diajak mengunjungi situs Kebo Iwa yang terletak di Pura Puseh Bedha. Pemandu lokal memberi edukasi kepada wisatawan dengan menjelaskan sejarah situs Kebo Iwa. Kunjungan berikutnya adalah Pura Telaga Suman, pemandu lokal memberi edukasi kepada wisatawan dengan menjelaskan sejarah dari pura ini dan keberadaan pohon bunut. Selanjutnya, wisatawan diajak menuruni anak tangga untuk menikmati air terjun dan melukat, yang merupakan tempat terakhir kunjungan setengah hari ini.

12.30 atau 13.30: Kembali ke hotel atau menikmati makan siang dengan menu masakan tradisional di Kawasan Grembengan dengan suasana alam

14.30: Pengantaran ke hotel di Nusadua/Kuta/Sanur/Ubud.

Paket Wisata Full Day Tour (pengelola destinasi merekomendasi obyek-obyek wisata mana yang bisa dikunjungi dalam waktu 8-9 jam atau satu hari), dengan contoh program:

08.30: Penjemputan dari hotel di Nusadua/Kuta/Sanur/Ubud ke Desa Bongan.

09.30: Tiba di Desa Bongan, tamu akan disuguhi keindahan agrowisata di Desa Bongan, yaitu menikmati suasana pedesaan dengan hamparan sawah hijau dan menyaksikan para petani mengolah sawah. Wisatawan diberikan edukasi dengan turut serta dalam membajak sawah, menanam dan memanen padi (tergantung 
periodenya). Di samping padi, wisatawan juga diajak untuk melihat tanaman sayur gonda dan memanennya atau menyaksikan proses sayur gonda menjadi teh gonda. Selesai menikmati keindahan agrowisata, wisatawan diantar ke kawasan Grembengan untuk melukat di tempat penyucian sambil menikmati keindahan air terjun.

13.30: Makan siang disajikan di tempat terbuka sambil menikmati suasana alam kawasan Grembengan.

14.00: Kunjungan setelah makan siang adalah Pura Telaga Suman yang masih berada di kawsan Grembengan. Pemandu wisata lokal juga menjelaskan keberadaan pohon besar di samping pura tersebut, serta tanaman di sekitarnya. Situs Kebo Iwa merupakan tempat terakhir pada full day tour di Desa Bongan. Pemandu lokal juga bisa menginformasikan keberadaan penangkaran burung Jalak Bali.

16.30: Pengantaran ke hotel di Nusadua/Kuta/Sanur/Ubud.

Program overnight dengan menginap di homestay juga bisa dibuat untuk wisatawan yang ingin mempelajari kawasan Grembengan atau Desa Wisata Bongan lebih dalam dan berinteraksi dengan masyarakat. Kesiapan homestay seperti ketersediaan sarana-prasarana sesuai protokol kesehatan harus dipastikan, guna kenyamanan dan keamanan wistawan.

\section{Identifikasi Activities}

Berbagai aktifitas di alam terbuka bisa dilakukan di kawasan Grembengan. Identifikasi terhadap aktifitas di kawasan Grembeng, antara lain melakukan kunjungan ke Pura Telaga Suman untuk mengamati/mempelajari arsitektur pura bernuansa budaya barat dan tradisional Bali. Kesegaran mata air dengan lingkungan yang asri dan alami bisa dirasakan wisatawan setelah selesai mengunjungi pura.

Wisatawan juga bisa menyaksikan proses pembuatan teh Gobo. Istilah Gobo berasal dari kata Gonda dan Bongan, gonda adalah nama jenis tanaman sayuran 
sebagai bahan baku teh, sedangkan Bongan adalah nama desa tempat lokasi kawasan Grembengan. Selain menikmati kesejukan di kawasan ini, wisatawan bisa mempelajari proses pembuatan teh Gobo, dimulai saat pemetikan tanaman gonda di ladang, proses penjemuran, pengeringan dan penyeduhan teh untuk diminum.

Aktivitas lain yang bisa dilakukan di kawasan ini adalah melakukan yoga baik di sekitar area air terjun atau di bawah pohon Bunut yang berusia ratusan tahun. Percikan air terjun dan kesejukan pohon akan memberikan pengalaman unik dalam melakukan yoga yang kemungkinan tidak diperoleh di tempat lain. Program outbound dengan berbagai permainan edukatif dan berkemah untuk kelompok wisatawan juga bisa dilakukan mengingat keberadaan area yang cukup lapang langsung terkena sinar matahari maupun di tempat sejuk di bawah pepohonan.

Identifikasi Ancilliary

Identifikasi terhadap ancillary services yang terdapat di kawasan Grembengan adalah area parkir untuk kendaraan roda dua yaitu sepeda motor yang terletak di area parkir yang terdapat di depan pintu masuk kawasan. Sedangkan, kendaraan roda empat yaitu mobil belum tersedia, sehingga pengunjung yang datang memakirkan kendaraannya di sepanjang jalan menuju kawasan tersebut. Berdasarkan hasil wawancara, pengelola sudah mempersiapkan lahan kosong di pinggir jalan yang akan difungsikan sebagai tempat parkir mobil.

Kawasan Grembengan yang terdiri dari beberapa tempat menarik, seperti Pura Telaga Suman, Pohon Bunut yang berusia ratusan tahun, tempat penyucian atau melukat dan air terjun, serta sungai tidak terdapat rambu-rambu penunjuk jalan menuju tempat-tempat tersebut. Pemberian rambu-rambu penunjuk jalan akan memudahkan wisatawan mencapai atau memilih tempat yang ingin dikunjungi terlebih dahulu.

Terkait pemenuhan fasilitas layanan lain, pengelola bernaung di organisasi kelompok sadar wisata Pesona Dewi Manis Bongan sebagai pengelola dan 
penanggung jawab yang berada di bawah naungan desa Wisata Bongan. Berdasarkan observasi lapangan, pengelola pokdarwis cukup transparan terhadap rencana program dengan sikap kekeluargaan dan gotong royong yang masih sangat kental. Sejak diperkenalkan kepada publik, pengelola berupaya maksimal dalam mengembangkan kawasan. Bentuk-bentuk upaya yang sudah dilakukan pengelola antara lain, mengadakan kerja sama dengan beberapa perguruan tinggi untuk memoles kawasan, membersihkan dan merapihkan kawasan, membuat tempat makan di area terbuka, memanfaatkan sayur gonda yang ada di lading sekitar kawasan untuk teh, memasang rambu-rambu edukatif sebagai pengingat untuk melaksanakan hidup sehat. Gambar 1 adalah kawasan Grembengan dengan rambu edukatif yang terpasang di lokasi.

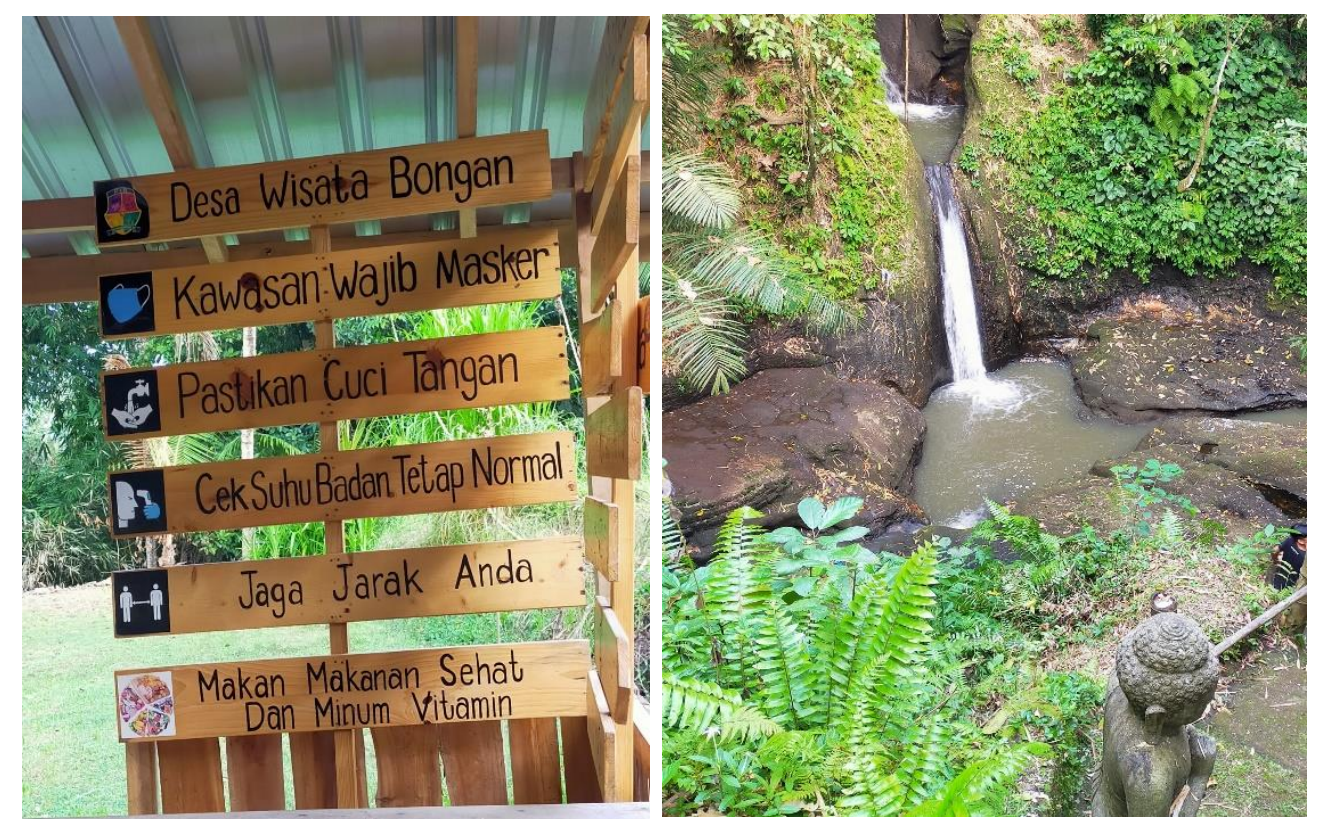

Gambar 1. Kawasan Grembengan dengan Rambu Edukatif Sumber: Hasil Observasi Peneliti 2021

\section{Kendala Kawasan Grembengan Menjadi Wisata Edukasi}

Besarnya potensi Grembengan menjadi destinasi wisata edukasi tidak semata pengelolaan kawasan tersebut berjalan dengan lancar. Berbagai kendala yang ada menjadi hambatan bagi pengembangan kawasan. Hasil observasi lapangan 
ditemukan ada dua masalah besar yang dapat diindentifikasi potensial menjadi penghalang dan perlu diselesaikan dengan baik.

Keterlibatan masyarakat dalam mengembangkan desa wisata dan kawasannya menjadi prasyarat mutlak. Namun, melibatkan masyarakat yang terdiri dari berbagai karakter individu yang berbeda agar mau berperan serta dalam proses pengembangan bukanlah hal yang mudah. Pemahaman kapasitas masing-masing individu terhadap desa wisata bisa berbeda satu dan lainnya, sehingga memerlukan waktu yang lama untuk meningkatkan kapasitas pemahaman tersebut. Permasalahan ini juga terjadi terhadap desa wisata Bongan, khususnya kawasan Grembengan.

Keberadaan pokdarwis Pesona Dewi Manis Bongan sebagai pengelola belum mampu membuat perubahan signifikan terhadap kawasan. Permasalahan internal organisasi, terkait perbedaan pemahaman antar anggota pokdarwis, mengakibatkan pembagian dan pengelompokkan kerja tidak berjalan sesuai struktur organisasi pokdarwis. Organisasi pokdarwis melibatkan unsur masyarakat sekitar dengan harapan masyarakat ikut andil dalam pembangunan kawasan. Namun kurangnya kesadaran, pemahaman dan pengetahuan masyarakat tentang desa wisata berdampak pada tingkat kepedulian masyarakat terhadap lingkungan, khususnya kawasan Grembengan masih kurang maksimal.

Di balik keindahan alam hijau di destinasi wisata kawasan Grembengan, ada tumpukan sampah di pinggiran sungai. Sampah menjadi salah satu masalah besar dalam setiap kegiatan pariwisata dan belum menjadi perhatian, khususnya di kawasan tersebut. Pengelola destinasi wisata lebih memilih fokus terhadap bagaimana mendatangkan wisatawan dibandingkan masalah sampah yang ada. Terutama saat musim hujan, sampah daun-daunan turut terbawa aliran air ke kolam pemandian. Tumpukan sampah dan tidak adanya kesadaran masyarakat untuk secara rutin bergotongroyong membersihkan area sungai menjadi kendala serius bagi kawasan. Hal ini dikrenakan sampah yang dibiarkan terus menurus semakin banyak, 
dapat merusak lingkungan. Penting bagi masyarakat yang digerakkan oleh pokdarwis melakukan pembersihan sampah sekitar sungai. Tindakan ini harus dilakukan demi menjaga keasrian kawasan dan menjadi destinasi wisata edukasi.

\section{Simpulan dan Saran}

Simpulan yang diambil dari uraian di atas adalah destinasi wisata kawasan Grembengan berpotensi menjadi wisata edukasi, dengan terpenuhinya identifikasi komponen pariwisata 6A. Potensi wisata edukasi kawasan diintegrasikan dalam komponen attraction, accessibility, amenity, package, activities, ancillary dan dikelola oleh pokdarwis selaku pengelola kawasan untuk menarik kunjungan wisatawan. Namun demikian, pokdarwis selaku organisasi yang melibatkan individu-induvidu sesuai dengan pembagian kelompok kerja belum mampu memaksimalkan keterlibatan masyarakat untuk mengatasi permasalahan yang ada di kawasan.

Saran yang dianjurkan adalah sebagai berikut, keterlibatan masyarakat sangat diperlukan guna pengembangan destinasi wisata, dalam hal ini pokdarwis harus berperan aktif memberdayakan masyarakat. Bentuk pemberdayaan masyarakat bisa dilakukan dengan berbagai sosialisasi atau penyuluhan, berbagai topik diskusi terkait potensi kawasan, penyelenggaraan kompetisi, atraksi seni dan budaya lokal. Bentukbentuk pemberdayaan tersebut harus diupayakan dan dilakukan secara terus menerus serta komprehensif sehingga masyarakat merasa peduli dengan kawasan tersebut.

\section{Ucapan Terima kasih}

Penulis menyampaikan terima kasih kepada masyarakat Desa Wisata Bongan yang telah menghadiri Forum Group Discussion khususnya Kelompok Sadar Wisata Dewi Manis Bongan. Penghargaan tinggi untuk Bapak I Nengah Makir dan Bapak Wayan Suarsa sebagai Ketua Desa Wisata Bongan yang aktif dalam diskusi dan 
memberikan informasi terkait situasi dan permasalahan yang dihadapi daya tarik wisata kawasan Grembengan.

\section{Daftar Pustaka}

Antara, Made dan Arida, Sukma. 2015. Panduan Pengelolaan Desa Wisata Berbasis Potensi Lokal. Bali: Konsorsium Riset Pariwisata (KRP) Universitas Udayana.

Devi, Ida Ayu Sinta, dkk. 2018. Potensi Objek Wisata Edukasi Di Kabupaten Gianyar. Jurnal Bosaparis: Pendidikan Kesejahteraan Keluarga Volume 9, Nomor 2, Juli 2018.

Dewi, Machya, dan Sri Issundari. 2013. “Desa Wisata Sebagai Aset Soft Power Indonesia." Masyarakat, Kebudayaan dan Politik 29(2): 64- 74

Eddyono, Fauziah. 2021. Pengelolaan Destinasi Pariwisata. Jawa Timur: Uwais Inspirasi Indonesia.

Harisandi, Yudhistira dan Muhammad Iqbal Anshory. 2019. Desa Wisata Edukasi Menuju Wisata Rakyat Berkelanjutan Di Kabupaten Situbondi (Wisata Edukasi Hidroponik Olean) Educational Tourism Village Towards Sustainable Community Tourism Situbondo (Olean Hydroponic Educational Tourism). Integritas: Jurnal Pengabdian Vol 3, No 2, Desember 2019. ISSN 2580-7978 (cetak). ISSN 25800794 (online)

Hariyanto, Oda I.B., dkk. 2018. Pengembangan Kampung Tulip Sebagai Wisata Edukasi di Bandung. Jurnal Pengabdian Kepada Masyarakat Vol. 1 No. 1 Februari 2018, Hal. 14-20. Jurnal Abdimas BSI.

Lumanauw, Nelsye. 2020. Perencanaan Paket Wisata Pada Biro Perjalanan Wisata Inbound (Studi Kasus Di PT. Golden Kris Tours, Bali. Jurnal Ilmiah Hospitality, 9(1), pp. 19-30. doi: 10.47492/jih.v9i1.26

Lumanauw, Nelsye. 2020. Manajemen Operasional Paket Wisata Perjalanan Insentif Di PT. Golden Kris Tours (Studi Kasus Rombongan Perusahaan Gunung Madu Lampung). JOURNEY Volume 2 Nomor 2, Juni 2020. ISSN 2654-9999

Priyanto, Priyanto, dkk. 2018. Perancangan Model Wisata Edukasi di Objek Wisata Kampung Tulip. Jurnal Pengabdian Kepada Masyarakat. Jurnal Abdimas BSI. Jurnal Pengabdian Kepada Masyarakat.

Sugiarti, Rara, dkk. 2017. Pengembangan Potensi Desa Wisata Di Kabupaten Ngawi. Cakra Wisata Vol 17 Jilid 2 Tahun 2016. 


\section{Profil Penulis}

Nelsye Lumanauw SE., M.Par. adalah dosen Program Studi Pengelolaan Konvensi dan Peristiwa (PKP) di Politeknik Internasional Bali (PIB), dan juga sebagai praktisi pariwisata di Bali. Penulis menyelesaikan Program Magister Pariwisata di Universitas Udayana tahun 2015. Program sarjana diselesaikan tahun 2011 di Fakultas Ekonomi Universitas Ngurah Rai Bali. Minat kuat terhadap bidang pariwisata menjadi alasan penulis bergabung di School of Tourism Manado tahun 1988-1989 dan meninggalkan pendidikan di Fakultas Sosial dan Politik Universitas Sam Ratulangi yang telah ditempuh pada tahun 1987-1988. Dunia kerja di pariwisata telah digeluti penulis sejak tahun 1989, berawal di Manado, dan pindah ke Bali tahun 1991 hingga sekarang. 